\title{
STRENGTHENING OF PLAIN CONCRETE MEMBERS USING FRP TECHNOLOGY
}

\author{
Ranganath T V L ${ }^{1}$, Raghu Yadav.G ${ }^{2}$ \\ ${ }^{1}$ Ph.D. student, civil engineering department, Himalayan University, Arunachala Pradesh \\ ${ }^{2}$ M.Tech student,Civil Engineering Department, Intell Engineering College, Ananthapur, Andhra Pradesh
}

\begin{abstract}
Fiber Reinforced Polymer (FRP) is a composite material made of a polymer matrix reinforced with fibers. FRP materials posses' superior mechanical properties like ability to carry loads, impact resistance, strength and stiffness. E-glass and carbon fiber FRP were selected for the present investigation. About 21nos. of plain concrete column specimens, 6 nos. of plain concrete beam specimens along with 4 concrete cubes were tested. M 20 grade of concrete was used to cast the above specimens. Single wrapping and double wrapping were the parameters for column specimens and wrapping in flexural zone only and wrapping in flexural zone and U clamp were the parameters for the beam specimens. The columns were tested for their compressive strength while the beams were tested for their flexural strengths under two point loading systems. The present investigation is to compare the enhancement of strength of plain columns and beams with E-glass and Carbon fibers.
\end{abstract}

Keywords: Fiber reinforced polymer, E-glass, carbon fiber, single wrap, double compressive strength, flexural strength.

\section{INTRODUCTION}

Fiber Reinforced polymer also known as Fiber Reinforced Plastic (FRP) is a composite material made of a polymer matrix reinforced with fibers. A composite material is a combination of two or more materials to form a third material. The purpose of using the composite material is to exploit the best properties of its components. The fibers that are commonly used are glass, carbon, aramid and basalt. FRP are generally used in construction industry and are increasingly acceptable to an alternative to steel reinforcement in Reinforced concrete structures. Resilience to corrosion is the advantage of FRP over steel reinforcement. Masonry structures can also be strengthened by FRP. The FRP can be used as original reinforcement and or for strengthening of existing structure.

When FRP materials are externally bonded to the structure, they act as external reinforcement to the structure. External reinforcing of structures by steel plates is now-a-days is replaced by strengthening FRP materials due to the advantage of superior strength-to- weight ratio of FRP materials.

Failure of concrete columns may result from crushing of the concrete due to either a lack of reinforcement or the fracture of the transverse hoop reinforcement and buckling of the longitudinal reinforcement ${ }^{[5]}$. For columns the maximum moment and strains occur at the ends of the column. The damage is generally limited to plastic zone. The use of FRP for strengthening of columns is an alternative to the conventional concrete. Now a day the use of FRP is gaining momentum worldwide.
The beams fail in flexure with the development of flexural cracks at the soffit of the mid span and or due to shear with the development of inclined shear cracks at the neutral axis at the support section. Applying of U wrap FRP for beams increases both the flexural and shear resistance of beams.

\section{HISTORY OF THE TECHNOLOGY}

P.N. Balaguru, Chang Peter $C$ and Perumal Samy ${ }^{[6]}$ have provided the basic information on the properties of fibers and matrices used for the composites and the basic behavior of the system. It is concluded that FRP is an effective repair material and long term durability and high temperature resistance are two issues to be resolved. It is also concluded that the combination of glass and carbon fibers proves to be economical than carbon alone.

Rajiv Nehru and Arpit Patni ${ }^{[1]}$ have presented the results of $5 \mathrm{RC}$ beams which were distressed, then strengthened and again loaded after strengthening with GFRP composites. It was reported that strengthened beams exhibit a delay in developing a first crack compared to control beams. Beams strengthened for flexure and shear performed excellently.

\section{OBJECTIVES OF THE PRESENT STUDY}

The present investigation is to study the effect of using EGlass and Carbon fiber on the load carrying capacity of plain concrete column and beam specimens. The scope of the study is to compare the performance of E-Glass and carbon fibers over controlled specimens and also to study the modes of failure, percentage change in load carrying capacity of column and beam specimens. 


\subsection{Types and Properties of FRP Used}

The main types of fibers used are Carbon fiber (CFRP) and E-Glass fiber (GPRF). E-Glass is the most common form used but it has the disadvantage of being attacked by the alkali in fresh concrete or grout. Typical properties of the FRP used are given in the table 1

Table -1: Typical FRP properties (dry fiber)

\begin{tabular}{|l|l|l|l|}
\hline & $\begin{array}{l}\text { E- Modulus } \\
(\mathrm{GPa})\end{array}$ & $\begin{array}{l}\text { Ultimate } \\
\text { strain (\%) }\end{array}$ & UTS(MPa) \\
\hline CFRP(sheet) & $240-640$ & $0.4-1.6$ & $2650-3800$ \\
\hline GFRP(sheet) & $65-75$ & $4.3-4.5$ & 2400 \\
\hline
\end{tabular}

\subsection{Properties of Other Materials Used}

Zuari cement 43grade confirming to IS-4031-1996 was used. The fine aggregates as per IS-2386-1963 - part III was used. Coarse aggregates used were confirming to IS 23861963-part III. Indian Standard method was used for the concrete mix design and the mix obtained was 1: 1.425:3.10. Weigh batched materials were mixed in a concrete mixer

\subsection{Details of Test Specimens}

The following table gives the details regarding the test specimens

Table-2 Details of Test specimens

\begin{tabular}{|c|c|c|c|}
\hline Sl.no. & $\begin{array}{l}\text { Specimen } \\
\text { Details }\end{array}$ & Dimensions & $\begin{array}{l}\text { No. of } \\
\text { specimens } \\
\text { tested }\end{array}$ \\
\hline \multirow[t]{4}{*}{1} & Columns & & \\
\hline & a) Control & $\begin{array}{l}150 \mathrm{~mm} \text {. dia and } \\
300 \mathrm{~mm} \text { height }\end{array}$ & 3 \\
\hline & $\begin{array}{l}\text { b) E-Glass } \\
* \text { Single wrap } \\
* \quad \text { Double } \\
\text { wrap } \\
\text { Partial } \\
\text { confinement } \\
* \text { Single wrap } \\
* \quad \text { Double } \\
\text { wrap }\end{array}$ & $\begin{array}{l}150 \mathrm{~mm} . \text { dia and } \\
300 \mathrm{~mm} \text { height }\end{array}$ & $\begin{array}{l}3 \\
3 \\
3 \\
3\end{array}$ \\
\hline & $\begin{array}{l}\text { C) Carbon } \\
\text { fiber } \\
\text { Partial } \\
\text { confinement } \\
* \text { Single wrap } \\
* \quad \text { Double } \\
\text { wrap } \\
\end{array}$ & $\begin{array}{l}150 \mathrm{~mm} . \text { dia and } \\
300 \mathrm{~mm} \text { height }\end{array}$ & $\begin{array}{l}3 \\
3\end{array}$ \\
\hline \multirow[t]{3}{*}{2} & Beams & & \\
\hline & a) control & $\begin{array}{l}100 \mathrm{mmX} 100 \mathrm{~mm} \\
\text { X } 450 \mathrm{~mm}\end{array}$ & 2 \\
\hline & $\begin{array}{l}\text { b) E-Glass } \\
* \text { Wrapped in } \\
\text { flexure zone } \\
\text { *combination } \\
\text { of wrapping in } \\
\text { flexure zone }\end{array}$ & $\begin{array}{l}100 \mathrm{mmX} 100 \mathrm{~mm} \\
\mathrm{X} 450 \mathrm{~mm}\end{array}$ & 1 \\
\hline
\end{tabular}

\begin{tabular}{|c|c|c|}
\hline and U- clamp & & \\
\hline $\begin{array}{l}\text { c) Carbon } \\
\text { Fiber } \\
* \text { Wrapped in } \\
\text { flexure zone } \\
\text { *combination } \\
\text { of wrapping in } \\
\text { flexure zone } \\
\text { and U- clamp }\end{array}$ & $\begin{array}{l}100 \mathrm{mmX} 100 \mathrm{~mm} \\
\mathrm{X} 450 \mathrm{~mm}\end{array}$ & 1 \\
\hline
\end{tabular}

\section{SPECIMENS AND TESTING EQUIPMENTS}

A total of 21 Nos. of column specimens, 6 Nos. of beam specimens and 4 Nos. of cube specimens were casted as show in fig. 1below.

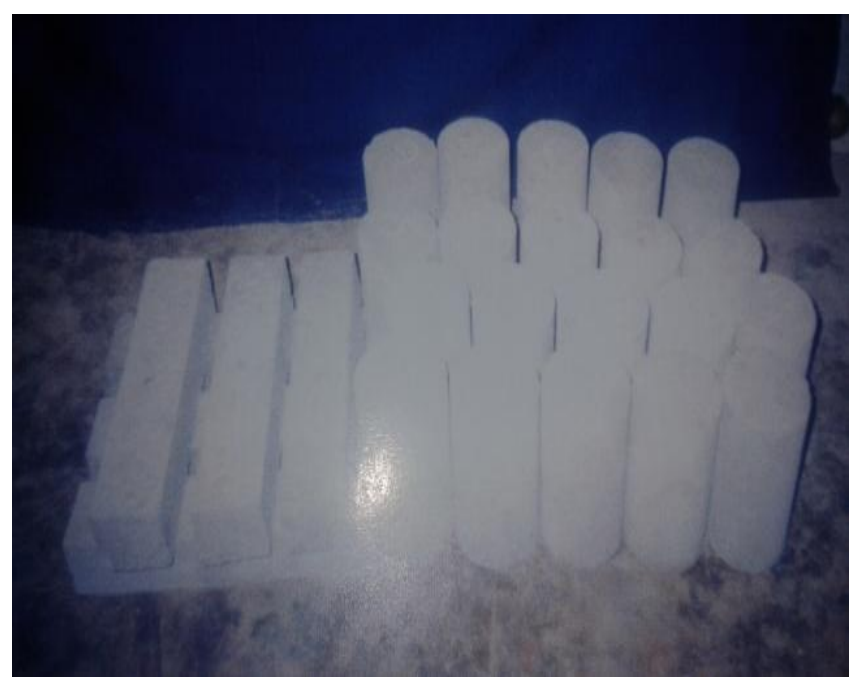

Fig.1- Specimen columns and beams

Except the control specimens the beams and columns were strengthened with FRP. The specimens after wrapping with FRP are shown in fig.2

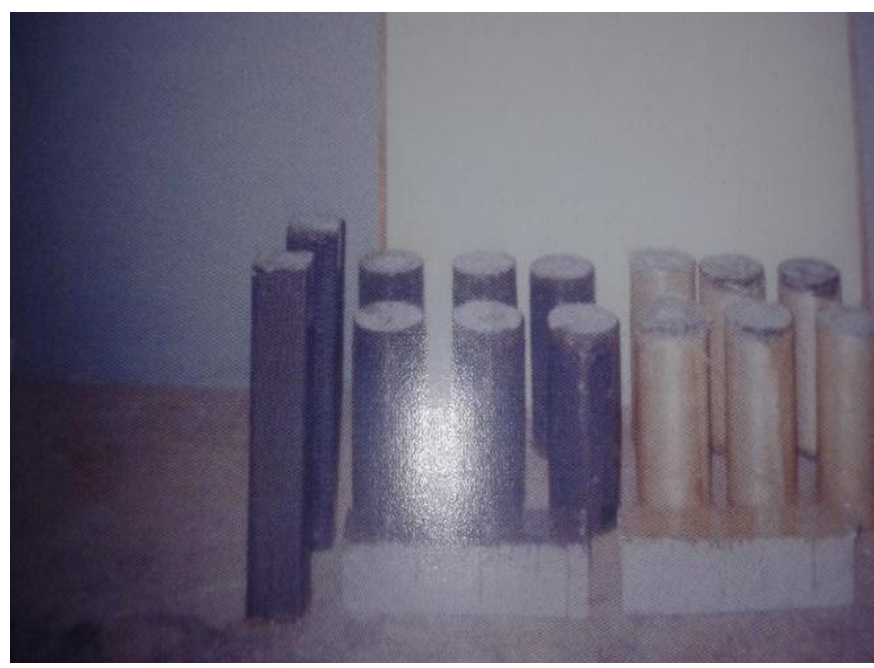

Fig 2- Specimens wrapped with carbon and glass FRP

The columns were axially loaded with a compression testing machine of 200 Tones capacity. 
The beams were tested for pure bending under two point loading with a flexural testing machine and a hydraulic jack of 100 Tones capacity.

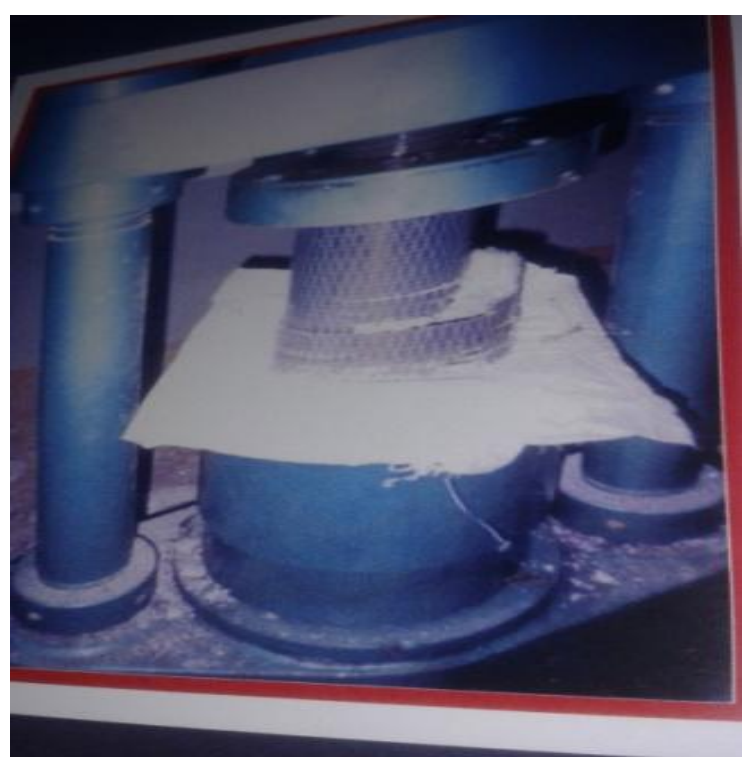

Fig 3Testing of columns

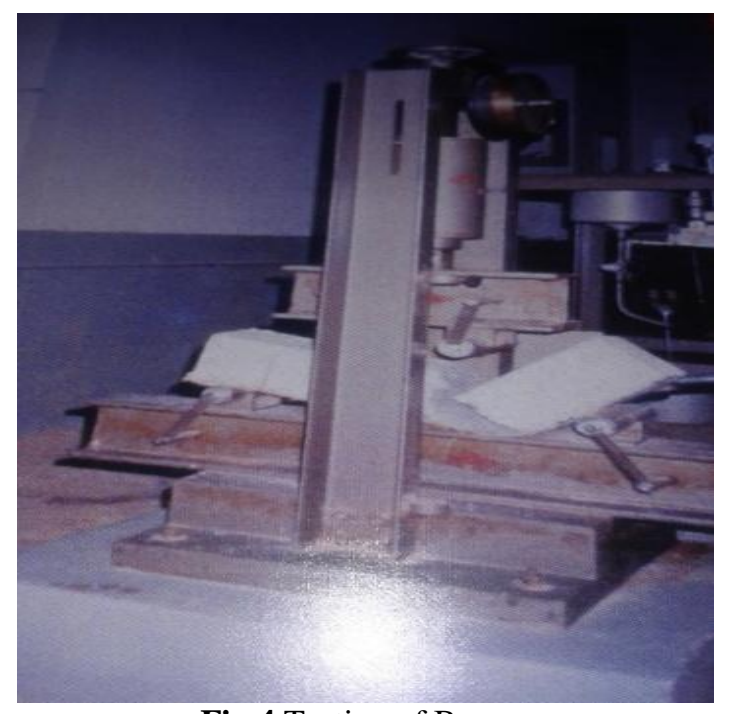

Fig.4 Testing of Beams

\subsection{Test Results}

Table-2 Behavior of columns with E-Glass fibers

\begin{tabular}{|c|c|c|c|c|}
\hline $\begin{array}{l}\text { Sl.No } \\
\text {. }\end{array}$ & $\begin{array}{l}\text { Colum } \\
\mathrm{n} \\
\text { Type }\end{array}$ & $\begin{array}{l}\text { Compressiv } \\
\text { e strength } \\
\text { in } \mathrm{N} / \mathrm{mm}^{2}\end{array}$ & $\begin{array}{l}\text { Average } \\
\text { Compressiv } \\
\text { e strength } \\
\text { in } \mathrm{N} / \mathrm{mm}^{2}\end{array}$ & $\begin{array}{l}\% \\
\text { increase } \\
\text { in g load } \\
\text { carrying } \\
\text { over } \\
\text { control } \\
\text { specimen } \\
\text { s }\end{array}$ \\
\hline 1. & C1 & 34.52 & \multirow{3}{*}{34.33} & \multirow{3}{*}{---- } \\
\hline & $\mathrm{C} 2$ & 34.52 & & \\
\hline 2. & C3 & 33.96 & & \\
\hline 3. & GC11 & 48.67 & \multirow[b]{2}{*}{59.80} & \multirow[b]{2}{*}{74.23} \\
\hline 4. & GC12 & 67.91 & & \\
\hline
\end{tabular}

\begin{tabular}{|c|c|c|c|c|}
\hline 5. & GC13 & 62.82 & & \\
\hline 6. & GC21 & 80.36 & \multirow{3}{*}{76.21} & \multirow{3}{*}{138.60} \\
\hline 7. & GC22 & 74.70 & & \\
\hline 8. & GC23 & 73.57 & & \\
\hline 9. & GCP11 & 48.10 & \multirow{3}{*}{50.36} & \multirow{3}{*}{46.73} \\
\hline 10. & GCP12 & 50.93 & & \\
\hline 11. & GCP13 & 52.06 & & \\
\hline 12. & GCP21 & 59.42 & \multirow{3}{*}{60.93} & \multirow{3}{*}{77.48} \\
\hline 13. & GCP22 & 62.25 & & \\
\hline 14. & GCP23 & 61.12 & & \\
\hline
\end{tabular}

Table-3 Behavior of columns with carbon fibers

\begin{tabular}{|c|c|c|c|c|}
\hline $\begin{array}{l}\text { Sl.No } \\
\text {. }\end{array}$ & $\begin{array}{l}\text { Colum } \\
\mathrm{n} \\
\text { Type }\end{array}$ & $\begin{array}{l}\text { Compressiv } \\
\text { e strength } \\
\text { in } \mathrm{N} / \mathrm{mm}^{2}\end{array}$ & $\begin{array}{l}\text { Average } \\
\text { Compressiv } \\
\text { e strength } \\
\text { in } \mathrm{N} / \mathrm{mm}^{2}\end{array}$ & $\begin{array}{l}\% \\
\text { increase } \\
\text { in g load } \\
\text { carrying } \\
\text { over } \\
\text { control } \\
\text { specimen } \\
\mathrm{s}\end{array}$ \\
\hline 1. & $\mathrm{C} 1$ & 34.52 & \multirow{3}{*}{34.33} & \multirow{3}{*}{---- } \\
\hline 2. & $\mathrm{C} 2$ & 34.52 & & \\
\hline 3. & C3 & 33.96 & & \\
\hline 4. & CCP11 & 54.90 & \multirow{3}{*}{56.02} & \multirow{3}{*}{63.12} \\
\hline 5. & CCP12 & 60.55 & & \\
\hline 6. & CCP13 & 52.63 & & \\
\hline 7. & CCP21 & 63.95 & \multirow{3}{*}{65.64} & \multirow{3}{*}{91.13} \\
\hline 8. & CCP22 & 72.44 & & \\
\hline 9. & CCP23 & 60.55 & & \\
\hline
\end{tabular}

Table-4 Test results for beam specimens

\begin{tabular}{|l|l|l|l|}
\hline Sl.No. & $\begin{array}{l}\text { Specimen } \\
\text { Type }\end{array}$ & $\begin{array}{l}\text { Ultimate } \\
\text { Moment } \\
\text { in Kn-m }\end{array}$ & $\begin{array}{l}\text { \% increase in } \\
\text { flexural } \\
\text { capacity over } \\
\text { control }\end{array}$ \\
\hline 1. & B1 & \multirow{2}{*}{1.79} & --- \\
\hline 2. & B2 & ---- \\
\hline 3. & GF & 2.33 & 30.16 \\
\hline 4. & GFC & 3.33 & 86.03 \\
\hline 5. & CF & 2.40 & 34.07 \\
\hline 6. & CFC & 4.00 & 123.46 \\
\hline
\end{tabular}

\section{DISCUSSION ON RESULTS AND}

\section{CONCLUSION}

Performance analysis test were conducted on plain concrete column specimens wrapped partially and fully with GFRP and fully with CFRP. Likewise conducted on beam specimens wrapped in flexure zone only and combination of wrapping flexure zone and $U$ clamp both with GFRP \&CFRP. The following conclusions were derived from experimental results:

1. It has been observed that there is an improvement in compressive strength of plain concrete columns when wrapped with single wrap $(74 \%)$, double wrap $(138 \%)$ and partially single wrap $(46 \%)$ and partially double wrapped $(77 \%)$ with E- glass fibers. Fully wrapped takes approximately $60 \%$ more load than partially wrapped with GFRP. 
2. It can be concluded from the test results that the compressive load carrying capacity will be increased for the partially wrapped single layered (63\%) and double $(91 \%)$ layered CFRP

3.The beams also improved their flexural strength when wrapped with FRP materials.

4. Carbon fibers are better than glass fibers in improving the compressive strength and flexural strength of plain concrete members.

\section{REFERENCES}

[1]. Rajiv Nehru and Arpit Patni, "Strengthening Reinforced Concrete Beams", Construction World, January 2003, pp.35-36.

[2]. Reichhold's FRP Material Selection Guide- An Engineer's Guide to FRP Technology. 2009. Pp.7-9,51-53.

[3]. www.aleicta.com ALEICTA guide- Strengthening of Reinforced concrete structures with externally bonded composite materials.

[4]. M.Sarafraz; F. Danesh, "Flexural Enhancement of RC columns with FRP", proceedings of the $14^{\text {th }}$ World conference on Earthquake Engineering, October 12-17, 2008, Beijing, China.

[5]. M.J.N preistley; F Seibel; G M Calvi, "Seismic design and Retrofit of Bridges" Wiley, 1996, pp-586-589.

[6]. P.N. Balaguru, N.Permalsamy and C.Chang"High strength composites for repair, rehabilitation and strengthening of concrete structures" ICI Journal Jan-Mar 2003.

[7].http://www.contech.co.nz/uploaded/Irwin_RahmanPap er.pdf

\section{BIOGRAPHIES}

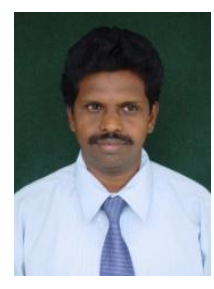

Ranganath T V L is currently working as associate professor and Head of the department in civil engineering faculty of B I T Institute of Technology, Hindupur, Andhra pradesh. Currently registered externally for Ph.D.course in Himalayan University, Arunachala Pradesh.

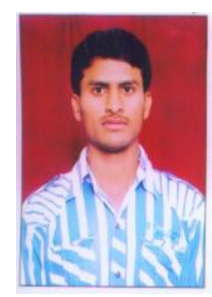

Raghu Yadav.G is graduated in civil engineering from Intell College of Engineering Ananthapur, affiliated to Jawaharalal Nehru Technological University, Ananthapur. Currently persuing Masters in structural engineering from the same Institute. 